\title{
Effect of traffic noise on Scinax nasicus advertisement call (Amphibia, Anura)
}

\author{
Evelina Leon ${ }^{1,2}$ (1) , Paola M. Peltzer ${ }^{2}$ (D), Rodrigo Lorenzon' (i) , Rafael C. Lajmanovich² (D) \\ \& Adolfo H. Beltzer ${ }^{1}$ (1)
}

\begin{abstract}
1. Instituto Nacional del Limnología, Laboratorio de Biodiversidad y Conservación de tetrápodos (INALI -UNL- CONICET), Ciudad Universitaria, Paraje "El Pozo", RN n 168, Km 472, (3000) Santa Fe, Argentina. (paolapeltzer@hotmail.com)

2. Laboratorio de Ecotoxicología, Facultad de Bioquímica y Ciencias Biológicas, Universidad Nacional del Litoral (FBCB -UNL-CONICET), Ciudad Universitaria, Paraje "El Pozo", RN N 168, Km 472, (3000) Santa Fe, Argentina.
\end{abstract}

Received 19 March 2018

Accepted 21 January 2019

Published 25 February 2019

$10.1590 / 1678-4766 e 2019007$

\begin{abstract}
Increased anthropogenic-made sounds such as traffic noises contribute to acoustic pollution, which produces deleterious effect on songvertebrates. We compared the advertisement call of Scinax nasicus (Cope, 1862) males in natural (as a reference or control, Site A) and Sites affected by traffic noises (Site B). Call structure was recorded and it was amplified in sonograms (software Raven Pro 1.5). Seven variables were measured on its advertisement call: duration (s), number of notes, number of pulses per note, maximum and minimum frequency (kHz), dominant frequency ( $\mathrm{kHz}$ ) and amplitude $(\mathrm{dB})$. In addition, at each Site the background noise (the fundamental frequency, F0 and amplitude, dB) was measured. The amplitude of background noise reached higher values $(68.02 \mathrm{~dB})$ in Site B, while in Site A was lower $(34.81 \mathrm{~dB})$. Thus, the F0 in Site A was 6.28 kHz and in Site B it was $4.15 \mathrm{kHz}$. Frog call in noisy environment (Site B) were characterized by lesser duration (s) and number of pulses per note, higher maximum and dominant frequencies $(\mathrm{kHz})$, lower minimum frequencies, and amplitude (dB) when compared with control environment (Site A). Our study highlights, that $S$. nasicus males shift their vocal structure in traffic noisy ponds, mainly by vocal "adjust" of their frequencies and amplitude to counteract masking effect. Finally, acoustic monitoring of anurans on noise environments should be considering the spatial, temporal and spectral overlap between noise and species-specific acoustic behaviour.
\end{abstract}

KEYWORDS. Amphibians, vocalization, vocal adjust, Hylidae.

RESUMEN. Efecto del ruído del tráfico en la vocalización de machos de Scinax nasicus (Amphibia, Anura). El aumento de los sonidos de origen antropogénico, como los ruidos del tráfico, contribuyen a la contaminación acústica, que produce un efecto nocivo en el canto de los vertebrados. Comparamos la vocalización de machos de Scinax nasicus (Cope, 1862) en ambientes naturales (como referencia o control, Sitio A) y sitios afectados por ruidos de tráfico (Sitio B). La estructura de la vocalización se registró y amplificó en sonogramas (software Raven Pro 1.5). Se midieron siete variables de su vocalización: duración (s), número de notas, número de pulsos por nota, frecuencia máxima, mínima y dominante (kHz) y amplitud (dB). Además, en cada sitio se midió el ruido de fondo (frecuencia fundamental, la F0 y amplitud, dB). La amplitud del ruido de fondo alcanzó valores más altos (68.02 $\mathrm{dB}$ ) en el Sitio B, en el Sitio A fue menor (34.81 dB). Por lo tanto, el F0 en el Sitio A fue de $6.28 \mathrm{kHz}$ y en el Sitio B fue de $4.15 \mathrm{kHz}$. Las vocalizaciones de esta rana en el ambiente con ruido de tráfico (Sitio B) se caracterizaron por menor duración (s) y número de pulsos por nota, mayor amplitud (dB) y frecuencias máximas y dominantes más altas $(\mathrm{kHz})$, baja frecuencia mínima en comparación con el ambiente control (Sitio A). Nuestro estudio resaltó que los machos de $S$. nasicus cambian su estructura vocal en estanques de ruido de tráfico, principalmente por "ajuste" vocal de sus frecuencias y amplitud para contrarrestar el efecto de enmascaramiento del ruido. Finalmente, el monitoreo acústico de anuros en ambientes ruidosos debe considerar el solapamiento espacial, temporal y espectral entre ruido acústico específico y el comportamiento de la especie.

PALABRAS CLAVES. Anfibios, vocalizaciones, ajustes vocales, Hylidae.

Investigations on acoustic communication in animals have provided some of the clearest demonstrations of the ways in which animals adapt to their environments. The transformation of natural habitats into urban areas not only reduces suitable habitat, but also increases anthropogenic sounds such as noise from vehicle traffic (WARREN et al., 2006). These habitat modifications produce alteration on vocal communications and interfere or mask social signals between animals that frequently occur near highways and where noise traffic is present (READ et al., 2014). The acoustic pollution by traffic noises, interfere with vocalizations of vertebrates, a phenomenon described as acoustic masking (BRUMM \&
SLABBEKOORN, 2005). The negative consequences of acoustic masking were well studied in several vertebrates groups, among them fishes (SLABbeKoorn et al., 2010; Voellmy et al., 2014), whales (CROLL et al., 2001; WARTZOK et al., 2003, BUCKSTAFF, 2004), seals (TERHUNE et al., 1979; RABIN et al., 2003), frogs (Sun \& NARINS, 2005), and birds (SLABbEKoORN \& Peet, 2003; Brumm, 2004; Halfwerk et al., 2011). Therefore, a widely source of acoustic pollution such as traffic noises, not only degrades habitats but it is also a significant stressor that impaired communication and alter behavioural (HALFWerk et al., 2011; Ortega, 2012; Francis et al., 2012) for many vocalizing organisms, including many amphibian 
species (BARBER et al., 2010; Nelson et al., 2016). In these vertebrates, changes in their vocalizations in response to high levels of traffic noises (Sun \& NARINS, 2005; LeNGAGNE, 2008; CUNNINGTON \& FAHRIG, 2010) reduce abundances and population composition. The demographic alteration may be due to disruption or partial masking of nuptial call that alter effective transmission distance (ETD), disorienting females towards a reproduction chorus, and preventing mate attraction (NARINS, 1982; WARREN et al., 2006; LeNGAGNE, 2008).

The noises above $60 \mathrm{~dB}$ produced by machines and vehicles are unrivalled in the natural world (WARREN et al., 2006); becoming acoustically polluted environments (SWADDLE \& PAGE, 2007). Differences in calling behaviour have been determined in several species of anurans in areas acoustically polluted with traffic noises (LENGAGNE, 2008; ENGBrecht et al., 2015; Kruger \& Du PreEz, 2016; CAORSI et al., 2017). There are not enough studies of how anuran response to noise pollution (SUN \& NARINS, 2005), and there are scarce in South America. Thus, it is mentioned that anthropogenic noise can suppress calling in some amphibians and it has direct and indirect complex effects. Conversely, among the effects reported that studied the influence of sounds produced by invasive species (CAORsI et al., 2017) or traffic noises on neotropical frogs (MedeIRos et al., 2017) stated out that may hinder species communication by decreasing or modifying signals. These alterations, consequently affect amphibian reproductive success and survival. These complex effects are well demonstrated in a variety of taxonomic groups across a range of scales, from the physiology and behaviour of individuals to changes at the population and community level (see BARBER et al., 2010; SLABBEKOORN et al., 2010).

The objective of our study was to analyse the advertisement call of Scinax nasicus, in environments with and without traffic noise in eastern Argentina. The hypothesis of our study is verified if the males of $S$. nasicus adjust their advertisement call presenting changes in call duration, number of notes per call, number of pulses per note, maximum and minimum frequency, dominant frequency and amplitude.

\section{MATERIALS AND METHODS}

Study area. Sampling Sites were located in Entre Ríos Province, mid-eastern Argentina. Many of the aquatic habitats in this area, that are crucial for anuran reproduction and survival, have been greatly altered to the point that existing amphibian populations may be dependent on altered wetlands or ephemeral ponds imbedded within or around urbanization or agricultural areas (PELTzER et al., 2003). The climate is temperate, with a mean annual temperature of $24( \pm 2)^{\circ} \mathrm{C}$ and mean annual precipitation of $995( \pm 100) \mathrm{mm}$.

Two types of Sites were selected for comparisons: natural (as a reference or control) and "noisy" ponds, hereby referred to as Sites A and B. The natural ponds (N $=3$, Site A, 31 40'29'S; 60²0'13'W) are located within a protected forest fragment (Parque General San Martín; PGSM) characterized by elements of flora and fauna of two Ecoregions: Espinal and Delta-Islas del Río Paraná
(BurkarT et al., 1999; Olson et al., 2001). These pluvial ponds are located in the inner area of this forest fragment situated more than $4 \mathrm{~km}$ away from the route. Thus, the “noisy" ponds $\left(\mathrm{N}=3\right.$, Site B, 31 ${ }^{\circ} 43^{\prime} 50^{\prime}$ 'S; 60²8'02”W) are located on one side of a two-lane route (National route -RN- number 12-Km 23.5) where due to the slope of the land several pluvial ponds are formed. In the last Site, ponds were $10 \mathrm{~m}$ away from the route. In this route the mean daily vehicular traffic ranged between 9500 and 10000 of heavy vehicles such as, cars, trucks and buses and a mean speed of $110 \mathrm{~km}$ (ATTADEMO et al., 2011).

In both Sites (Sites A, B), particular attention was paid to the following features: (1) all ponds were primary permanent water bodies; and (2) the ponds were $100 \mathrm{~m}$ apart one from another. The most common vegetation emerged or surrounded the edge of all ponds, common named as transitional zones between terrestrial and aquatic ecosystems (zones ecotones that connects water bodies with their adjacent uplands, ZAIMES et al., 2010), included cattails (Typha latifolia), willow (Salix humboldtiana), burhead (Echinodorus grandiflorus), pampas grass (Cortaderia selloana), duckpotatoe (Sagittaria montevidensis), smartweed (Polygonum punctatum), and rush (Juncus pallescens). The pond areas ranged from $120 \mathrm{~m}^{2}$ to $3000 \mathrm{~m}^{2}$. Whereas microhabitat temperature fluctuations are possible, temperature was measured with a digital thermometer $\left(0.1^{\circ} \mathrm{C}\right)$ in each Site, to avoid microhabitat scale effect on frog's call (NELSON et al., 2017).

Species selected. The snouted tree frog, Scinax nasicus (Cope, 1862), is a small (SVL 27-35 mm; CEI, 1980) hylid frog with flat body and triangular snout, tympanum easily visible limited above by an oblique supra-tympanic fold, and slightly constricted neck. This species is well-adapted to climb due to its adhesive disks on tips of fingers and toes and conical subarticular tubercles. It breeds from late spring to late summer. Its distribution include Argentina, Bolivia, Brazil, Paraguay, and Uruguay, where is frequently found in natural, urban and agricultural environments (PELTZER \& LAJMANOVICH, 2007). The conservation status of this frog is "Least Concern" according to KWET et al. (2004). A single type of note, with a mean of five pulses, composes the advertisement call. The call duration is $0.05-0.35 \mathrm{~s}$, with a frequency spectrum that ranges from about 0.8 to $3.9 \mathrm{kHz}$ and a dominant frequency ranged between $0.85-1.11 \mathrm{kHz}$. The note duration varied between $0.04-0.1 \mathrm{~s}$, whereas the notes are separated by a mean of $0.1 \mathrm{~s}$ intervals, and pulses per note varied between 2 and 4 (DE LA Riva et al., 1994; Luis Fernando Marin da Fonte, unpubl. data).

Environmental noise. Environmental noise was recorded for five-minute periods one hour before sunset. In accordance of the microhabitat vocalization of $S$. nasicus (in the edge of ponds, SANCHEZ et al., 2013), in both Sites the records were made in the ecotones. To standardize all records in both Sites, the distance from the edge of ponds was two meter and the recorder instrumental was placed at a height of one meter. The records were similarly in both Sites to allow comparison and provide the environmental noise that characterize the habitat frog's vocalization. 
Acoustic records. The environmental noise and $S$. nasicus advertisement call components of each Site were studied over the course of one breeding season (December 2013 - February 2014, N = 32 nights) by analysing both environmental noises and frog call structure from sonograms.

Environmental noise and frog call were recorded with a multidirectional microphone (Panasonic PN-666) that was mounted in a fiberglass parabola $(55 \mathrm{~cm}$ in diameter) connected to a Sony TCM - 400DV tape recorder. In spite of the simplicity of the components used, these provide excellent directionality and noise reduction (BUDNEY \& GrotKe, 1997; LeON et al., 2015).

Frog advertisement vocalization. The call of male frogs ( $\mathrm{N}=39$ Site $A, N=59$ Site $\mathrm{B})$ was recorded from each type of Site. These acoustic records were started one hour before sunset and it was continued for three hours. Each call was recorded at a distance of $50 \pm 5 \mathrm{~cm}$ from the frog. At least $10 \mathrm{~min}$ were allowed to pass between individual frog recordings to allow surrounding frogs to recover from any disturbance caused by the observers. All the frogs recorded were located $70-80 \mathrm{~cm}$ above the soil surface, mainly on herbs such as pampas grass (C. selloana), in order to avoid variation in habitat selection, temperature, and humidity, once these factors influence the enhancement or attenuation of different frequencies (CATCHPOLE et al., 1995; ZOLLINGER \& BRUMM, 2015). Additionally, once a frog was localized, all observation movements and light disturbance from flashlights were stopped for five minutes before recording in order to allow the frog to continue normal calling behaviour. Observers walking in only one direction around the breeding Site (HEYER, 1994) minimized the probability of recording the same as frog during a night survey. After call recording, the males were captured and measured (snout-vent length) with a digital caliper $( \pm 0.01 \mathrm{~mm})$, then they were released in the same Site.

Analyses of environmental noise and vocalization. The mean Site's amplitude (dB) and the fundamental frequency (F0) were measured from sonograms of environmental acoustic records of each Site. The section from each environmental acoustic record that contained the highest noise level was selected. The recording of the sound in each Site consisted on three continuous minutes of duration. Then, they were scanned and saved as ASCII and WAVE files. Each sample was reduced from three to one minute, to facilitate further analysis, selecting from the original recording 3 to 20 -second portions (first 20 s., 20 central s., and 20 final s.). Because the noise (mainly those produced by humans and machines) is composed of low fundamental frequencies, the average amplitude used was that contained in the analysed elements below $0.60 \mathrm{kHz}$, a filter of frequencies lower than this value was applied, since the sound below said frequency corresponds to the interference by high voltage antennas in the area. Then, a Fourier analysis was performed, obtaining a spectrogram frequency spectrum of each ambient sound portion. These environmental noises are below the calls emitted by anurans, as demonstrated by CUNNINGTON \& FAHRIG (2010).
Following KöHLER et al. (2017), seven variables were measured on frog's call: call duration (s), number of notes per call, number of pulses per note, maximum and minimum frequency $(\mathrm{kHz})$, dominant frequency $(\mathrm{kHz})$ and amplitude of call (dB). Frog call structure was amplified in the sonograms of environmental noise by using software RAVEN Pro 1.5 (sampling frequency: $44.100 \mathrm{~Hz}$, FFT length: 4096, time resolution: $2.90 \mathrm{~ms}$., frequency resolution $5.38 \mathrm{kHz}-$ The Cornell Lab of Ornithology, Ithaca, NY, USA).

Statistical analysis. The environmental temperatures of the ponds studied were averaged by Sites (A, B) and then these mean temperatures in each sample period were compared using a Mann-Whitney U test, to ensure that frog's call were recorded under the same temperatures (PARRIS et al., 2009). Similarly, snout vent length (size) of males in the different point samples of each Site were compared with one tailed paired $t$-student test. Frog's call variables (duration-s, number of pulses per note, maximum and minimum frequency, dominant frequency-kHz, and amplitude- $\mathrm{dB}$ ), as well as mean background noise (amplitude and fundamental frequency-F0) were analysed with a one tailed paired t-student test to compute the statistical significance between Sites. Multidimensional scaling (NMDS) was applied to ordinate samples based on frog's acoustic variables and to explore graphically whether these variables varied in the Sites. Bray - Curtis dissimilarity was used as resemblance measure of frog's acoustic variables between Sites. R (R CORE TEAm, 2018) with vegan package (OKSANEN et al., 2013) was utilized for all statistical analyses. For the construction of figures the ggplot2 package was used (WICKHAM, 2016).

\section{RESULTS}

The environmental noise showed differences in amplitude (dB) and fundamental frequencies (F0) in both Sites. The mean amplitude in Site A was lower $(34.81 \mathrm{~dB})$ than that recorded in Site B $(68.02 \mathrm{~dB})(t=7.79, \mathrm{df}=81.2$, $\mathrm{p}<0.05$, Fig. 1 A1, B1). Noises in Site B were produced by traffic (cars, motorcycles, and trucks) on road. The fundamental frequency (F0) in Site A was $6.28 \mathrm{kHz}$ while in Site B $4.15 \mathrm{kHz}(t=6.89, \mathrm{df}=76.1, \mathrm{p}<0.05$; Fig 1. A2, $\mathrm{B} 2$, respectively). In addition, environmental temperatures were similar $(\mathrm{U}=3.50, \mathrm{p}<0.05)$ in the two Sites (Site A mean $=25 \pm 1{ }^{\circ} \mathrm{C}$; Site B mean $=25 \pm 2.3{ }^{\circ} \mathrm{C}$ ) during the studied period. Male sizes were similar $(t=8.4, \mathrm{df}=96$, $\mathrm{p}>0.05$ ) in both Sites (Site A mean $=32 \pm 2 \mathrm{~mm}$; Site B mean $=31 \pm 1.5 \mathrm{~mm}$ ).

The amplitude of call between Site A $(28 \pm 3.01$ dB, Fig. A3) and Site B $(35 \pm 0.05$ dB, Fig. B3 $)$ differed significantly $(t=2.72, \mathrm{df}=81.9, \mathrm{p}<0.001)$. The analysis of the spectrograms (Fig 1. A4, B4) showed that the duration of frog call in Site A $(0.30 \pm 0.02 \mathrm{~s})$ was longer than Site $\mathrm{B}(0.15 \pm 0.01 \mathrm{~s})$, these values are significantly different $(t=2.12, \mathrm{df}=57.2 \mathrm{p}<0.05)$. The number of notes for both Sites was $\mathrm{N}=1$, whereas the mean number of pulses per note was significantly higher $(t=3.21, \mathrm{df}=61.5, \mathrm{p}<0.001)$ in Site A $(4.07 \pm 0.38)$ than in Site B $(2.5 \pm 0.16)$. The 

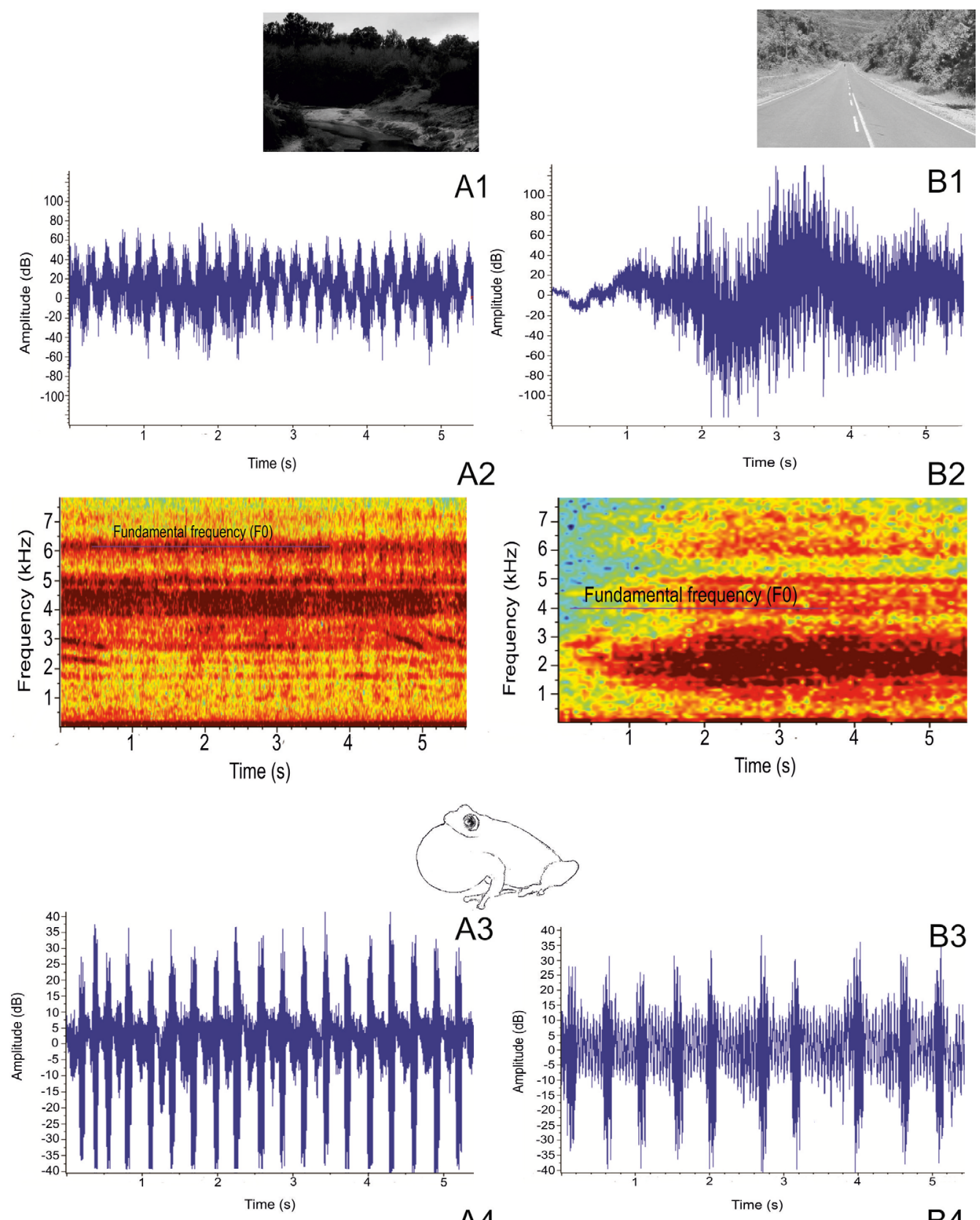

A4
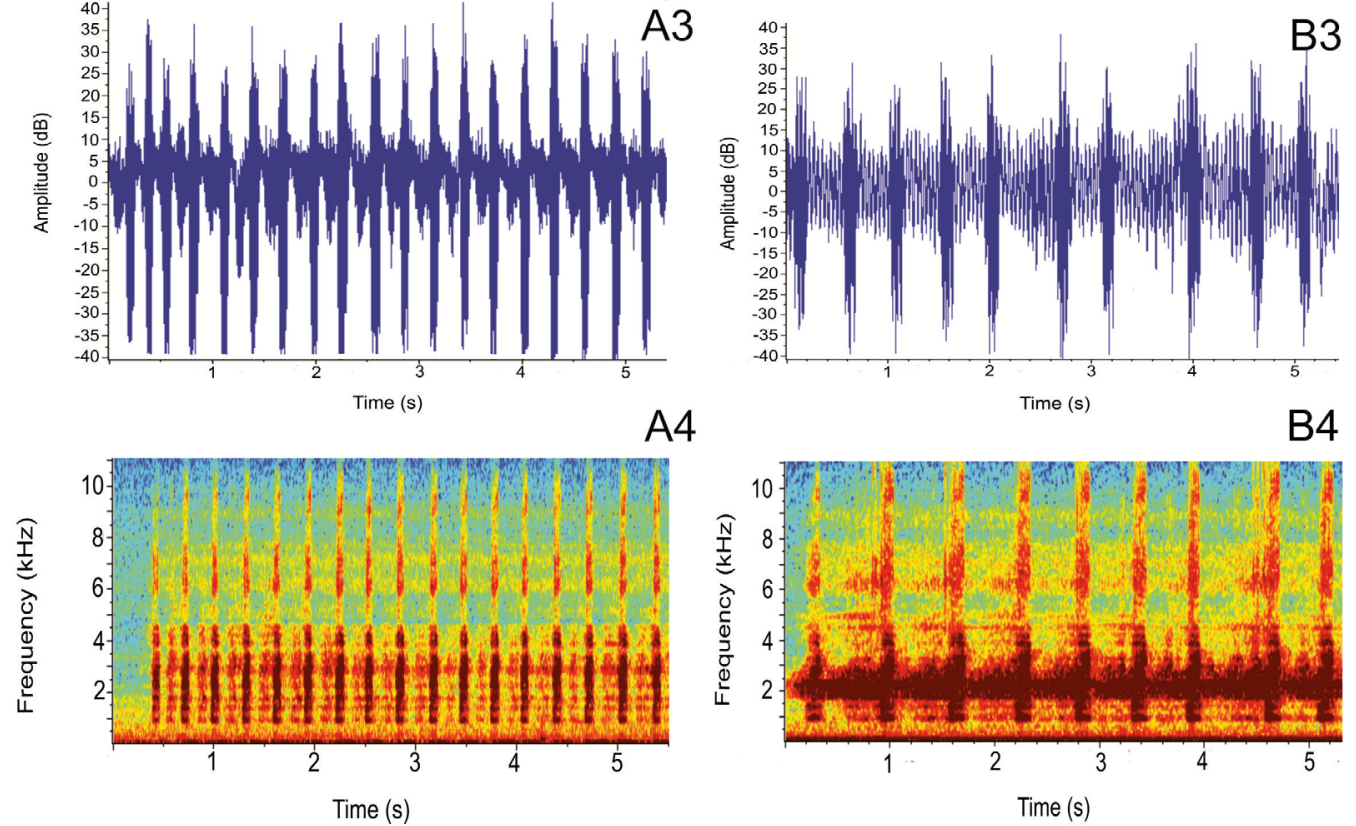

Fig 1. Noise backgrounds and Scinax nasicus (Cope, 1862) call parameters at reference (Site A) and noisy environments (Site B). Amplitude (oscillograms A1, B1) and frequency (spectrograms A2, B2) of the environments. Amplitude (oscillograms A3, B3) and frequency (spectrograms A4, B4) of the advertisement frog's call. 
maximum frequency in Site A was $2.80 \pm 0.09 \mathrm{kHz}$, being significantly lower $(t=5.22, \mathrm{df}=74.4, \mathrm{p}<0.0001)$ than Site B $(3.79 \pm 0.08 \mathrm{kHz})$. On the contrary, the minimum frequencies was significantly higher $(t=5.28, \mathrm{df}=49.7, \mathrm{p}<0.0001)$ in Site A $(1.16 \pm 0.53 \mathrm{kHz})$ than Site B $(0.67 \pm 0.23 \mathrm{kHz})$. The dominant frequency was significantly higher $(t=5.19$, $\mathrm{df}=44.12, \mathrm{p}<0.00001)$ in Site $\mathrm{B}(2.62 \pm 0.02 \mathrm{kHz})$ than in Site A $(2.02 \pm 0.06 \mathrm{kHz})$.

The number of pulses per note, minimum frequency, and duration of frog's call were different at the first dimension of NMDS. In addition, Bray - Curtis dissimilarity distances formed two distinct groups (Sites A and B, Fig. 2) according to frog's call variables (except for number of notes).

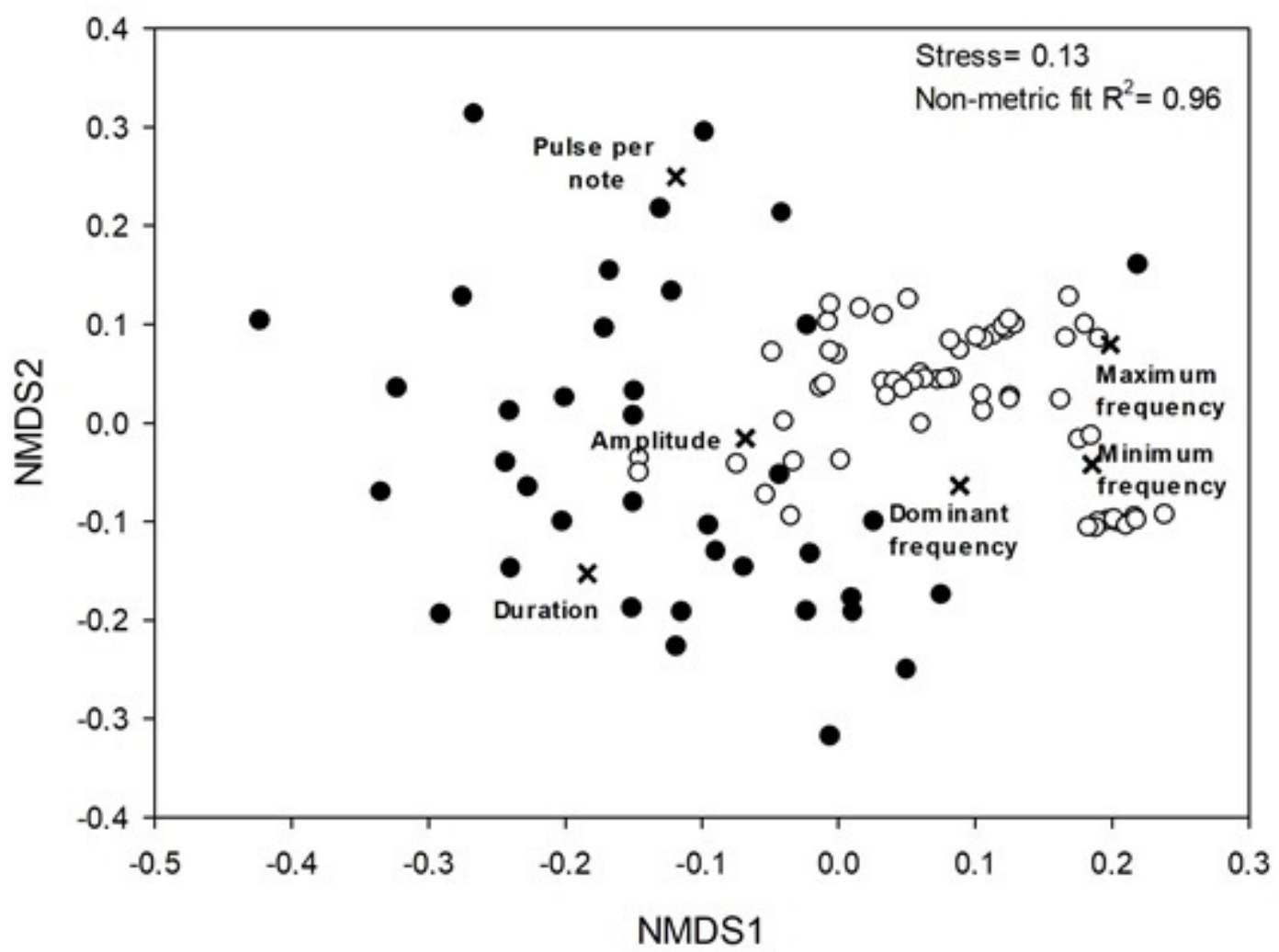

Fig 2. Non-metric multidimensional scaling (NMDS) ordination of call variables of Scinax nasicus (Cope, 1862) adult males in natural (filled circles, Site A) and noisy environments (empty circles, Site B) Sites. The minimum frequency and duration as well as the displayed note pulse of the frogs call were different between the Sites in the first dimension.

\section{DISCUSSION}

Our study demonstrated that the traffic noise at breeding ponds closer to road (Site B) had higher amplitudes (68.02 dB), where Scinax nasicus adjusts its advertisement call (shorter duration with higher amplitude, lower number of pulses per note, variation in range of maximum, minimum, and dominant frequencies). No differences in temperature or frog's size were found between Sites, indicating that frog's call were recorded under similar temperature avoiding microhabitat effect (PARRIS et al., 2009), and controlling body size (BRUMM, 2004). It is revealed in amphibians that traffic noise interfere with the transmission channel characteristics and threat their survival (TroÏANOWSKI, et al., 2017). As regard, noise pollution is a potential underestimated threat that affects species highly dependent of acoustic communication (CAORsi et al., 2017).

Scinax nasicus produced calls with shorter duration in the traffic noisy Site (Site B, $68.02 \mathrm{~dB}$ ), and differed to advertisement call of $S$. nasicus from wet subtropical forest (DE LA RIVA et al., 1994). Thus, call's frog modification as a response to increase in acoustic pollution by traffic were found in the hylids Dryophytes cinereus and D. versicolor (Fellers, 1979), and the dendrobatid Andinobates bombetes (VARGAS-SALINAS \& AmÉZQUiTA, 2013). On the other hand, not only there is evidence of vocal adjustments with respect to traffic, FARIA et al. (2013) found that Scinax squalirostris, modified the duration and number of pulses per note of its call due to a geographical variations, indicating may be a co-generic vocal adjustment when they are exposed to environmental or geographical situations.

Generally, anuran amphibians alter their frequency's call to avoid overlap with the fundamental frequency of the anthropogenic-noisy environments, explaining the variation observed in maximum, minimum and dominant frequencies of frog's call, in order to mitigate the effect of masking noise (SUN \& NARINS, 2005; RocA et al., 2016). In addition, it is likely that the increase in the dominant frequency in noisy 
Sites increase the attraction of the females (ZHAO et al., 2017). Scinax nasicus increase above of $0.60 \mathrm{kHz}$ of its dominant frequencies in noise Sites. Similarly, PARRIs et al. (2009) demonstrated that the pelodryadid Litoria ewingii and the myobatrachid Crinia signifera increase more than 0.10 and $0.15 \mathrm{kHz}$ their dominant frequencies in Sites with highest traffic noise levels. In addition, WARREN et al. (2006) pointed out that low fundamental frequency generally characterizes anthropic environments such as recorded in Site B (4.15 $\mathrm{kHz}$ ), and they stated that song species in such environments alters its frequency signals.

Strategies for flexible signal adjustment in noisy environments involve an increase in amplitude call that reduces masking impacts (HALFWERK \& SLABBEKOORN, 2009; PoHL et al., 2009). In general, the noisy environment can alter females' ability to orient toward the signal emitted by males (phonotaxis), and therefore the probability of attracting other males or females (BEE \& SwANSON, 2007; BARBER et al., 2010; Nelson et al., 2016). Several species of frogs have been shown to alter call amplitudes during noise exposure (Penna \& Hamilton-West., 2007). Shen \& Xu (2016) showed that the Chinese frog Odorrana tormota increases amplitude of its call in response to increasing noise level, similarly to $S$. nasicus call's amplitude from Site B ( $35 \mathrm{~dB})$. Similarly, to frequencies variation, the increase in frog's call amplitude in a noisy environment may increase the reception of the signal by the females. These short-term behavioural responses presumably improve signal detection by receivers (CUNNINGTON \& FAHRIG, 2013) and thus may contribute to maintaining successful communication in noisy habitats (SLABBEKOORN, 2013). The sublethal effects of noise, including physiological stress, energy cost and impaired reproduction remain poorly understood (CUNNINGTON \& FAHRIG, 2010; Kight \& Swaddle, 2011). Furthermore, higher amplitude observed in frog's call from noisy Sites may be explained in terms of the Lombard effect (LOMBARD, 1911), a common response to counteract masking from background noise (WARREN et al., 2006), that is well demonstrated for different amphibian species (SUN \& NARIS, 2005; HALFWERK et al., 2016; SHEN \& Xu, 2016).

CunNINGTON \& FAHRIG (2010) demonstrated that four anuran species (Lithobates clamitans, L. pipiens, Dryophytes versicolor, Anaxyrus americanus) altered their vocalization when motorbike noises increased $(>60 \mathrm{~dB}$ ) on roads in Eastern North America. These authors also noted that frog species had a plastic vocalization during communication due to anthropic noises. Such vocal plasticity allows frogs to have a broader tolerance to environmental sound levels (PADilla \& AdolPh, 2005; Ghalambor et al., 2007; Wells $\&$ SCHWARTS, 2007).

Anthropic noise creates another form of habitat loss (BARBER et al., 2010), and anurans may be vulnerable to acoustic habitat modification (BEE \& SwANSON, 2007). Our results and tested hypothesis contribute to the growing evidence that the singing vertebrates steadily alter vocal behaviour as increasing environment noises (REIJNEN et al., 1995). It has been demonstrated that these noises produce not only a shift in frog calls but also physiological stress (e.g. higher level of corticosterone), and impair breeding migration behaviour (WITTE et al., 2001; TENNESSEN et al., 2014), consequently affecting their fitness (SUN \& NARINS, 2005) and population dynamics (KAISER \& HAMMERS, 2009).

This first approach in an Argentinean frog provides evidence of call responses in sites with and without anthropic acoustic pollution produced mainly by traffic. We concluded that $S$. nasicus shifts its vocal signal design (amplitude and frequency) in aquatic sites near to paved roads characterized by higher mean amplitude and low fundamental frequencies of background noises. We recommend that advertisement call of anuran amphibians should be considered as behavioural biomarker to monitor acoustic pollution in anthropic soundscapes.

Acknowledgments. We thank to M. Attademo, L. Sanchez, G. Urich, and C. Junges for assistance in the field samples, and A. Berduc for allowing us to work in their natural forest. To Lic. Alejandra Scotti for English assistance service. To Patrick Colombo and referees that greatly improve early version. The study was partially support by the project UADER - grant no. 784/06.

\section{REFERENCES}

Attademo, M. A.; Peltzer, P. M.; Lajmanovich, R. C.; Elberg, G.; Junges, C.; SAnchez, L. \& BAsso, A. 2011. Wildlife vertebrate mortality in roads from Santa Fe Province, Argentina. Revista Mexicana de Biodiversidad 82:915-925.

Barber, J. R.; Krooks K. R. \& Fristrup, K. M. 2010. The costs of chronic noise exposure for terrestrial organisms. Trends Ecology Evolution 25:180-189.

Bee, M. A. \& Swanson, E. M. 2007. Auditory masking of anuran advertisement calls by road traffic noise. Animal Behaviour 74:17651776.

Brumm, H. 2004. The impact of environmental noise on song amplitude in a territorial bird. Journal of Animal Ecology 73:434-440.

Brumm, H. \& Slabbekoorn, H. 2005. Acoustic communication in noise. Advances in the Study of Behaviour 35:151-209.

BUCKSTAFF, K. C. 2004. Effects of watercraft noise on the acoustic behavior of bottlenose dolphins. Marine Mammal Science 20:709-725.

Budney, G. F. \& Grotke, R. 1997. Techniques for audio recording vocalizations of tropical birds. Ornithology Monographs 48:147-163.

Burkart, R.; Bárbaro, N.; Sánchez, R. O. \& Gómez, D. A. 1999. Ecoregiones de la Argentina. Buenos Aires, Programa de desarrollo institucional, componente de política ambiental, Administración de Parques Nacionales. 42p.

Caorsi, V. Z.; Both, C.; Cechin, S.; Antunes, R. \& Borges-Martins, M. 2017. Effects of traffic noise on the calling behavior of two Neotropical hylid frogs. PLoS ONE 12(8):e0183342.

Catchrole, C. K.; Slater, P. J. \& Song, B. 1995. Biological Themes and Variations. New York, Cambridge University Press. 241p.

Croll, D. A.; Clark, C. W.; Calambokidis, J.; Elllison, W. T. \& Tershy, B. R. 2001. Effect of anthropogenic low frequency noise on the foraging ecology of Balaenoptera whales. Animal Conservation 4:13-27.

Cunnington, G. M. \& Fahrig, L. 2010. Plasticity in the vocalizations of anurans in response to traffic noise. Acta Oecologica 36:463-470.

Cunnington, G. M. \& FAHrig, L. 2013. Mate attraction by male anurans in the presence of traffic noise. Animal Conservation 16(3):275-285.

De La Riva, I.; Márquez, R. \& Bosch, J. 1994. Advertisement calls of Bolivian species of Scinax (Amphibia, Anura, Hylidae). Bijdragen tot de Dierkunde 64(2):75-85.

Engbrecht, N. J.; Heemeyer, L. J.; Murphy, C. G.; Stiles, R. M.; Swan, J. W. \& LANNOO, M. J. 2015. Upland calling behavior in Crawfish Frogs (Lithobates areolatus) and calling triggers caused by noise pollution. Copeia 103(4):1048-1057. 
Faria, D. C.; Signorelli, L.; Morais, A. R.; Bastos, R. P. \& Maciel, N. M. 2013. Geographic structure and acoustic variation in populations of Scinax squalirostris (A. Lutz, 1925) (Anura: Hylidae). North-western Journal of Zoology 9(2):329-336.

FeLLERS, G. M. 1979. Aggression, territoriality, and mating behaviour in North American treefrogs. Animal Behaviour 27:107-119.

Francis, C. D.; Kleist, N. J.; Davidson, B. J.; Ortega, C. P. \& Cruz, A. 2012. Behavioral responses by two songbirds to natural-gas-well compressor noise. Ornithological Monographs 74:36-46.

Ghalambor, C. K.; Mckay, J. M.; Carroll, S. P. \& Reznick, D. N. 2007. Adaptive versus non adaptative phenotypic plasticity and the potential for contemporary adaptation in new environments. Functional Ecology 21:394-407.

Halfwerk, W. \& SLABbeKoorn, H. 2009. A behavioural mechanism explaining noise-dependent frequency use in urban birdsong. Animal Behaviour 78: 1301-1307.

Halfwerk, W.; Hollemann, L. J. M.; Lessells, C. M. \& Slabbekoorn, H. 2011. Negative impact of traffic noise on avian reproductive success. Journal of Applied Ecology 48:210-219.

Halfwerk, W.; Lea, A. M.; Guerra, M.; Page, R. A. \& Ryan, M. J. 2016. Vocal responses to noise reveal the presence of the Lombard effect in a frog. Behavioral Ecology 27:669-676.

Heyer, W. R. 1994. Recording frog calls. Pp. 285-287. In: HeYer, W. R.; Donnelly, M. A.; McDiarmid, R. W.; HayeK, L. \& Foster, M. S. eds. Measuring and Monitoring Biological Diversity. Standard Methods for Amphibians. Washington D.C., Smithsonian Institution Press. 384p.

Kaiser, K. \& Hammers, J. L. 2009. The effect of anthropogenic noise on male advertisement call rate in the neotropical treefrog, Dendropsophus triangulum. Behaviour 146:1053-1069.

Kight, C. \& Swaddle, J. P. 2011. How and why environmental noise impact animals: an integrative, mechanistic review. Ecology Letters 14:1052-1061.

KöHler, J.; Jansen, M.; RodríGuez, A.; KoK, P. J. R.; Toledo, L. F.; Emmrich, M.; Glaw, F.; Haddad, C. F. B.; Rödel, M. O. \& VENCES, M. 2017. The use of bioacoustics in anuran taxonomy: theory, terminology, methods and recommendations for best practice. Zootaxa 4251(1):001-124.

Kruger, D. J. D. \& Du Preez, L. H. 2016. The effect of airplane noise on frogs: a case study on the Critically Endangered Pickersgill's reed frog (Hyperolius pickersgilli). Ecological Research 31(3):393-405.

Kwet, A.; Aquino, L.; Reichle, S.; Silvano, D.; Lavilla, E.; Di Tada, I. \& LANGONE, L. 2004. Scinax nasicus. The IUCN Red List of Threatened Species 2004: e.T55980A11390205. Available at $<$ http://dx.doi. org/10.2305/IUCN.UK.2004.RLTS.T55980A11390205.en>. Accessed on 19 January 2019.

Leon, E. J.; Beltzer, A. H.; Olguín, P. F.; Reales, C. F.; Urich, G. V.; Alessio, V. \& Quiroga, M. A. 2015. Song structure of the golden-billed saltator (Saltator aurantiirostris) in the middle Parana river floodplain. Bioacoustics 24(2): 145-152.

Lengagne, T. 2008. Traffic noise affects communication behaviour in a breeding anuran, Hyla arborea. Biological Conservation 141(8):20232031.

Lombard, E. 1911. Le signe de l'e' le'vation de la voix. Ann Malad l'Oreille 37:101-119.

Medeiros, C. I.; Both, C.; Grant, T. \& Hartz, S. M. 2017. Invasion of the acoustic niche: variable responses by native species to invasive American bullfrog calls. Biological Invasions 19:675-690.

NARINS, P. M. 1982. Effects of masking noise on evoked calling in the Puerto Rican coquí (Anura: Leptodactylidae). Journal of Comparative Physiology. A, Neuroethology, Sensory, Neural, and Behavioral Physiology 147(4):439-446.

Nelson, D. A.; Szeyller, E. \& Poesel, A. 2016. Alerting and message components of white-crowned sparrow song differ in structure and environmental transmission. Behaviour 153:263-285.

Nelson, D. V.; Klinck, H.; Carbaugh-Rutland, A.; Mathis, C. L.; Morzillo, A. T. \& Garcia, T. T. 2017. Calling at the highway: The spatiotemporal constraint of road noise on Pacific chorus frog communication. Ecology and Evolution 7(1):429-440.

Oksanen, J.; Blanchet, F. G.; Kindt, R.; Legendre, P.; Minchin, P. R.; O’hara, R. B.; Simpson, G. L.; Solymos, P.; Stevens, M. H.
H. \& Wagner, H. 2013. vegan: Community Ecology Package. R package version 2.0-10. Available at $<$ http://CRAN.R-project.org/ package $=$ vegan $>$. Accessed on 6 May 2017 .

Olson, D. M.; Dinerstein, E.; Wikramanayake, E. D.; Burgess, N. D.; Powell, G. V. N.; Underwood, E. C.; D’Amico, J. A.; Itoua, I.; Strand, H. E.; Morrison, J. C.; Loucks, C. J.; Allnutt, T. F.; Ricketts, T. H.; Kura, Y.; Lamoreux, J. F.; Wettengel, W. W.; HedAo, P. \& KaSSEM, K. R. 2001. Terrestrial ecoregions of the world: a new map of life on Earth. Bioscience 51(11):933-938.

ORTEGA, C. P. 2012. Effects of noise pollution on birds: a brief review of our knowledge. Ornithological Monographs 74:6-22.

Padilla, D. K. \& Adolph, S. C. 2005. Plastic inducible morphologies are not always adaptive: the importance of time delays in a stochastic environment. Evolutionary Ecology 10:105-117.

Parris, K.; Velik-Lord, M. \& North, J. 2009. Frogs call at a higher pitch in traffic noise. Ecology and Society 14(1):25.

Penna, M. \& Hamilton-West, M. C. 2007. Susceptibility of evoked vocal responses to noise exposure in a frog of the temperate austral forest. Animal Behaviour 74:45-56.

Peltzer, P. M. \& Lajmanovich, R. C. 2007. Amphibians. In: Iriondo, M. H.; PAGGI, J. C. \& PARMa, M. J. eds. The middle Paraná River: limnology of a subtropical wetland. New York, Springer, p. 327-340.

Peltzer, P. M.; Lajmanovich, R. C. \& Beltzer, A. H. 2003. The effects of habitat fragmentation on amphibian species richness in the floodplain of the middle Parana River. Herpetological Journal 13(2):95-98.

Pohl, N. U.; Slabbekoorn, H.; Klump, G. M. \& Langemann, U. 2009. Effects of signal features and environmental noise on signal detection in the great tit, Parus major. Animal Behaviour 78:1293-1300.

Rabin, L. A.; McCowan, B.; Hooper, S. L. \& Owings, D. H. 2003. Anthropogenic noise and its effect on animal communication: An interface between comparative psychology and conservation biology. International Journal of Comparative Psychology 16:172-192.

R Core Team. 2018. R: A language and environment for statistical computing. R Foundation for Statistical Computing, Vienna, Austria. Available at $<\mathrm{https}: / / \mathrm{www} . R$-project.org/>. Accessed on 12 April 2018.

ReAd, J.; Jones, G. \& RADFord, A. N. 2014. Fitness costs as well as benefits are important when considering responses to anthropogenic noise. Behavioral Ecology 25:4-7.

Reijnen, R.; Foppen, R.; Ter BraAK, C. \& ThisSen, J. 1995. The effects of car traffic on breeding bird populations in woodland. III. Reduction of density in relation to the proximity of main roads. Journal of Applied Ecology 32:187-202.

Roca, I. T.; Desrochers, L.; Giacomazzo, M.; Bertolo, A.; Bolduc, P.; Deschesnes, R.; Martins, C. A.; Rainville, V.; Rheault, G. \& ProulX, R. 2016. Shifting song frequencies in response to anthropogenic noise: a meta-analysis on birds and anurans. Behavioral Ecology 27:1269-1274.

Sanchez, L. C.; Peltzer, P. M.; Lajmanovich, R. C.; Manzano, A. S.; Junges, C. M. \& Attademo, A. M. 2013. Reproductive activity of anurans in a dominant agricultural landscape from central-eastern Argentina. Revista Mexicana de Biodiversidad 84(3):912-926.

Shen, J. X. \& Xu, Z. M. 2016. The Lombard effect in male ultrasonic frogs: Regulating antiphonal signal frequency and amplitude in noise. Scientific Reports 6:27103.

SlabbeKoorn, H. 2013. Songs of the city: noise-dependent spectral plasticity in the acoustic phenotype of urban birds. Animal Behaviour 85(5): 1089-1099.

Slabbekoorn, H. \& Peet, M. 2003. Ecology: Birds sing at a higher pitch in urban noise. Nature 424:267.

Slabbekoorn, H.; Bouton, N.; Van Opzeeland, I.; Coers, A.; Ten Cate, C. \& POPPER, A.N. 2010. A noisy spring: the impact of globally rising underwater sound levels on fish. Trends Ecology and Evolution 25:419-427.

SUn, J. W. C. \& NARINS, P. A. 2005. Anthropogenic sounds differentially affect amphibian call rate. Biological Conservation 121:419-427.

Swaddle, J. \& Page, L. C. 2007. High levels of environmental noise erode pair preferences in zebra finches: implications for noise pollution. Animal Behaviour 74(3):363-368.

Tennessen J. B.; Parks, S. E. \& LAngKILde, T. 2014. Traffic noise causes physiological stress and impairs breeding migration behaviour in frogs. Conservation Physiology 2(1):cou032. 
Terhune, J. M.; Stewart, R. E. A. \& Ronald, K. 1979. Influence of vessel noise on underwater vocal activity of harp seals. Canadian Journal of Zoology 57:1337-1338.

Troïanowski, M.; Mondy, N.; Dumet, A.; Arcanjo, C. \& Lengagne, T. 2017. Effects of traffic noise on tree frog stress levels, immunity and color signaling. Conservation Biology 31(5):1132-1140.

VArgas-Salinas, F. \& AmÉzQuita, A. 2013. Stream Noise, Hybridization, and Uncoupled Evolution of Call Traits in Two Lineages of Poison Frogs: Oophaga histrionica and Oophaga lehmanni. PLoS ONE 8(10): 77545.

Voellmy, I.; Purser, J.; Flynn, D.; Kennedy, P.; Simpson, S. \& Andrew, R. 2014. Acoustic noise reduces foraging success in two sympatric fish species via different mechanisms. Animal Behaviour 89:191-198.

Warren, P. S.; Katti, M.; Ermann, M. \& Brazel, A. 2006. Urban bioacoustics: it's not just noise. Animal Behaviour 71(3):491-502.

WartzoK, D.; Popper, A.; Gordon, J. \& MerriL, J. 2003 Factors affecting the responses of marine mammals to acoustic disturbance. Marine Technology Society Journal 37(4):6-15.
Wells, K. D. \& Schwarts, J. J. 2007. The behavioral ecology of anuran communication. In: NARINS, P. M.; Feng, A. S.; FAY, R. R \& PopPer, A. N. eds. Hearing and Sound Communication in Amphibians. New York, Springer, p. 44-85.

Wiскнам, H. 2016. ggplot2. Elegant araphics for data analysis. Series, Use R! New York, Springer. 186p.

Witte, K.; Ryan, M. J. M. \& WilczTnSKI, W. 2001. Changes in the frequency structure of a mating call decrease its attractiveness to females in the cricket frog Acris crepitans blanchardi. Ethology 107:685-699.

Zaimes, G. N.; Iakovoglou, V.; Emmanouloudis, D. \& Gounaridis, D. 2010. Riparian Areas of Greece: Their Definition and Characteristics. Journal of Engineering Science and Technology Review 3(1):176-183.

Zhao, L.; Zhu, B.; Wang, J.; Brauth, S. E.; Tang, Y. \& Cui, I. 2017. Sometimes noise is beneficial: stream noise informs vocal communication in the little torrent frog Amolops torrentis. Journal of Ethology 35:259.

Zollinger, S. A. \& Brumm, H. 2015. Why birds sing loud songs and why they sometimes don't. Animal Behaviour 105:289-295. 